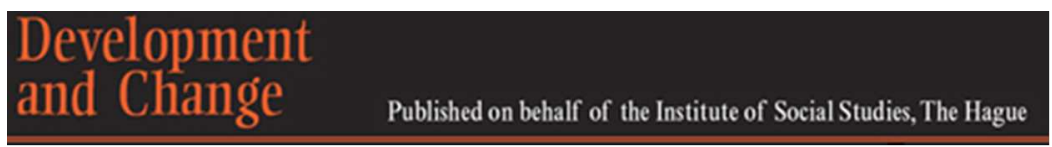

\title{
The social regulation of markets. Why microcredit fails to promote jobs in rural South India
}

\begin{tabular}{|c|c|}
\hline Journal: & Development and Change \\
\hline Manuscript ID: & $\mathrm{DECH}-13-232 . \mathrm{R} 2$ \\
\hline Manuscript Type: & Original Article \\
\hline Date Submitted by the Author: & 17-Feb-2015 \\
\hline Complete List of Authors: & $\begin{array}{l}\text { Guérin, Isabelle; Institute of Research for Development, Cessma; French } \\
\text { Institute of Pondicherry, } \\
\text { D'Espallier, Bert; Hogeschool-Universiteit, } \\
\text { Venkatasubramanian, G.; French Institute of Pondicherry, }\end{array}$ \\
\hline Keywords: & $\begin{array}{l}\text { Southern Asia < Regions, Microfinance }<\text { General, Labour }<\text { General, } \\
\text { Gender }<\text { General, Discrimination < General, Methodology }<\text { General, } \\
\text { Political economy < General }\end{array}$ \\
\hline Abstract: & $\begin{array}{l}\text { There is growing evidence that microcredit does little to support self- } \\
\text { employment. Two main explanations are typically emphasized. From a } \\
\text { microeconomic perspective, the poor have been argued to lack the skills, } \\
\text { resources and motivation to start their own businesses. From a } \\
\text { macroeconomic perspective, local markets are often saturated. In this } \\
\text { paper, we use first-hand data from rural South India to explore a third } \\
\text { explanation focussing on the social regulation of markets. Drawing on a } \\
\text { household survey, we show that self-employment and microcredit are } \\
\text { uncorrelated, and that women and lower castes have a significantly lower } \\
\text { chance of starting up a business. The businesses they do start tend to be } \\
\text { smaller, less profitable and based in very specific sectors. Our qualitative } \\
\text { insights into the workings of local economies show that caste and gender- } \\
\text { based social regulations influence local markets determining who can } \\
\text { produce or sell what, to whom, and at what price. We observe that real } \\
\text { markets are affected by power relations and structured through social } \\
\text { institutions rather than being the sum of interactions between free and } \\
\text { competitive individuals. These findings show the importance to integrate } \\
\text { self-employment programmes into broader policies for transforming the } \\
\text { social regulation of markets and for eradicating discrimination against } \\
\text { women and lower castes. caste and gender-based social regulations have } \\
\text { an impact on local markets, determining who can produce or sell what, to } \\
\text { whom, and to some extent at what price. Our findings highlight the need to } \\
\text { integrate 'self-employment' programmes into broader policies for } \\
\text { transforming how markets are socially regulated. }\end{array}$ \\
\hline
\end{tabular}


Page 1 of $27 \quad$ Development and Chans

SCHOLARONE"
Manuscripts 


\title{
The social regulation of markets Why microcredit fails to promote jobs in rural South India ${ }^{1}$
}

\begin{abstract}
There is growing evidence that microcredit does little to support self-employment. Two main explanations are typically emphasized. From a microeconomic perspective, the poor have been argued to lack the skills, resources and motivation to start their own businesses. From a macroeconomic perspective, local markets are often saturated. In this paper, we use first-hand data from rural South India to explore a third explanation focussing on the social regulation of markets. Drawing on a household survey, we show that self-employment and microcredit are uncorrelated, and that women and lower castes have a significantly lower chance of starting up a business. The businesses they do start tend to be smaller, less profitable and based in very specific sectors. Our qualitative insights into the workings of local economies show that caste and gender-based social regulations influence local markets determining who can produce or sell what, to whom, and at what price. We observe that real markets are affected by power relations and structured through social institutions rather than being the sum of interactions between free and competitive individuals. These findings show the importance to integrate self-employment programmes into broader policies for transforming the social regulation of markets and for eradicating discrimination against women and lower castes.
\end{abstract}

Key words: microcredit, gender, caste, institutions, power, markets, India

\section{Introduction}

Can promoting self-employment offer an effective way out of poverty? The debate on self-employment, poverty and development has swung back and forth over the second half of the twentieth century. In the early 1970s, researchers and policymakers came to agree on the potential of small businesses to help develop local economies (ILO, 1972). But they also observed that these emerging local economies were typically 'informal' (Hart, 1973), beyond any form of regulation, and that businesses struggled to become profitable. It was often thought that such informal self-employment would disappear as local economies modernized and formalized.

\footnotetext{
${ }^{1}$ Field work was carried out between 2008 and 2012 within the research project Rural Microfinance and Employment: Do Processes Matter? funded by the French National Agency for Research (ANR).
} 
Since the 1990s, social scientists and development planners experienced the complexity of moving beyond an informal economy and realized that developing the informal sector can in fact facilitate agrarian transitions and industrialization. At a time of structural economic adjustments where jobs could no longer be provided by the state, self-employment began to be promoted as both an individual safety net and an accelerator to local development (Turnham et al., 1990). The first decade of the twenty-first century marked the peak of this praise for self-employment and the success of microcredit that came with it. 2005 was declared the International Year of Microcredit, with the goal of "building inclusive financial sectors and strengthening the powerful, but often untapped, entrepreneurial spirit existing in communities around the world" ${ }^{, 2}$. When Muhammad Yunus and the Grameen Bank were awarded the Nobel Peace Prize in 2006, the Nobel Committee affirmed that "across cultures and civilisations, Yunus and Grameen Bank have shown that the poor can work to bring about their own development [...] Micro-credit promotes entrepreneurship $^{3}$, and puts each individual poor person, especially women, in the driving-seat of their own lives"4.

Today, however, self-employment policies have been increasingly questioned. Several years ago, various in-depth studies pointed out the difficulties of making entrepreneurs out of the poor via microcredit (Servet, 2006). This was shown for instance for Senegal (Perry, 2002), Egypt (Elyachar, 2006) and Bangladesh (Rahman, 1999). These findings, however, were regarded as exceptions since the chosen research method of focusing on just a few villages or neighbourhoods made generalisations problematic. More recent studies have shown that most microcredit is in fact used for consumption rather than incomegenerating activities (Morduch, 2013) and as a consequence it has had a limited impact on job creation.

Two main points have been raised to explain this. First, a microeconomic perspective has been taken to argue that the poor lack the skills, resources or motivation to start their own business. This has been one of the main conclusions of recent experimental studies (see for instance Banerjee and Duflo, 2011). In his book Why doesn't microfinance work? Bateman (2010) looks at the other side of the coin, namely markets and macroeconomic development to back up arguments already made by authors as Servet (2006, 2010), Davis (2006), and Karnani (2011). Microcredit promoters' biggest mistake, Bateman argues, is their ignorance of composition effects and their naive adherence to a particular interpretation of the law of Say, by which supply creates its own demand. Local markets are very often already saturated. New and expanded microcredit-induced microbusinesses do not develop local demand but merely redistribute it

\footnotetext{
${ }^{2}$ http://www.yearofmicrocredit.org.

${ }^{3}$ Yunus does not really discuss the term 'entrepreneurship'. Here we use simpler terms such as 'small businesses' or 'self-employment'. Discussing the various forms of entrepreneurship is beyond the scope of this paper.

${ }^{4}$ http://www.nobelprize.org/nobel_prizes/peace/laureates/2006/presentation-speech.html
} 
which results in a variety of displacement effects i.e. new businesses replacing old ones, and the tendency for profitability to fall (Bateman, 2010, pg. 66-73).

We believe, however, that the literature has ignored the social and hierarchical features of markets as a further explanatory factor. Political economics has long highlighted the subordinate relationships of small businesses to larger entities within the capitalist sector, especially in the literature on agrarian change and petty commodity production (Moser, 1978; Williams, 1982). Economic subordination has been found to go hand in hand with social discrimination, defined here as specific social groups facing restrictions or differential treatment (Harriss-White, 2012).

This paper will explore the social structures of self-employment by examining how gender and casteinduced social norms affect the likelihood and success of self-employment. Caste and gender determine access to crucial resources for entering the market. Moreover, these social variables feed into the social institutions of power that shape, regulate and define the operating rules of markets.

There have already been a number of empirical studies on the Indian microcredit market. Some have clearly shown that gender, caste and class relationships influence microcredit outcomes. Women from low castes and classes are either excluded from self-help group schemes, or unable to use them effectively (Garikipati, 2008; Pattenden, 2011; Rao, 2008). To complement these studies, our focus is on the challenges of business creation and the workings of markets more generally which received little prior attention. Our paper applies hand-collected data from a survey of 1,929 people from 405 households in rural South India, alongside 10 years of observation of village economies.

We find that, while microcredit is widespread across the region, the chance of being self-employed is statistically uncorrelated to microcredit. Women and lower castes (Dalits) have a significantly lower chance of starting up a business, controlling for individual, household and geographical differences. Finally, there are significant differences in the type of businesses created. Women tend to create smaller business and are less likely to hire extra employees. Businesses set up and run by the lowest castes are typically smaller and younger. Those started up by women and the lowest castes are significantly less profitable in terms of annual income. Our qualitative insights can further explain the underlying processes and mechanisms at play. They also highlight the key role of social institutions in shaping the structure of markets and their hierarchical dimensions.

We believe this paper makes a number of important policy contributions. First, it shows that microcredit is unsuccessful in stimulating job creation. The most vulnerable households are in fact least likely to start up a sustainable income-generating activity. This also implies that microcredit can only be an effective job creation mechanism if certain preconditions are met. These include the alleviation of the social, cultural and political barriers women and lower castes face. As it stands, microcredit tends to reinforce rather than 
alleviate social inequalities, given the types of businesses women and lower castes create. Furthermore, our findings shed light on the social construction of markets, and the need to integrate self-employment policies into a broader project for changing how markets are socially structured and regulated.

\section{A literature review on 'self-employment' and 'market-conceptualization'}

The World Bank Development Report 2013 (World Bank, 2013) states that nonfarm self-employment varies widely from $20 \%$ to $60 \%$ of men and women's combined employment in developing countries. This figure is highest in Africa (around 45\% on average) and lowest in Europe and Central Asia and South Asia (with an average of around 15\% and 20\% respectively). For India, the 2009-2010 National Sample Survey suggests that total self-employment can rise to $50 \%$ of the total working population (NSS $66^{\text {th }}$ round) and non-farm self-employment to around 20\% (Srivastava, 2012).

There is no agreement whether self-employment still has the potential to grow. This depends on how the market is conceptualized. One viewpoint is that markets are intrinsically productive. They allow individual creativity and competition to flourish, which are both considered as "driving forces for all innovations, technological changes and better management" (Yunus, 2007). This ideological take on markets is central to the concept of 'popular capitalism' propounded by bestselling economists such as De Soto (The Mystery of Capital, 2003) and Prahalad (The Fortune at the Bottom of the Pyramid, 2004) and further expanded upon by Yunus (A World Without Poverty, 2007). Various barriers have been argued to keep the poor from accessing markets. These include a lack of credit or property rights, or simply not being seen as a profitable market opportunity for larger companies. Poor people are however assumed to have unlimited yet often hidden 'entrepreneurial spirit'. Once the above barriers are removed, it is argued, their creative talents can be fully tapped and equal market participation becomes possible. Some empirical studies support this view. A broad empirical study in Latin America funded by the World Bank found that while self-employment can be precarious and unprofitable for a few individuals, it benefits the majority (Maloney, 2004). The World Bank has also widely supported this view in its own reports (see for instance World Bank, 2004).

Recent studies have adopted a more nuanced perspective, exploring the vast diversity of self-employment. They have highlighted the differences between 'opportunity' and 'necessity', 'push' and 'pull' factors, and 'growth-oriented' and 'survivalist-oriented' self-employment (De Mel et al., 2010; Verrest, 2012; Ligthelms, 2005 ; Grimm et al., 2012; Berner et al., 2012). These studies' bottom line is that genuine growth-oriented entrepreneurs do exist but the vast majority of the self-employed are simply struggling to survive in a difficult, often saturated and low-growth setting (Cling et al., 2015). 
The above studies neglect the structural preconditions for self-employment to flourish. In a highly abstracted approach, markets are viewed as an aggregation of individuals. Taking successful advantage of the market opportunities is a matter of individual characteristics. Randomized studies, which have become widely accepted as the most rigorous impact assessment method for development policies, including microcredit, have pushed such a microeconomic approach to an extreme. Banerjee and Duflo (2011) have notably used insights from behavioural economics to explain the failures of specific markets (such as credit, insurance or savings markets) in broadly psychological or cognitive terms. They have acknowledged that many small businesses have remained tiny and poorly profitable with little growth prospects. But they offer no convincing explanation for this, simply commenting: "It is too hard" (ibid., pg. 223). Individuals who can successfully run larger firms may have some kind of "special skill or a much larger up-front investment" (ibid., pg. 221). Social institutions such as gender or caste are ignored as potential obstacles to self-employment.

Livelihood studies try to take into account the full range of human, social, natural, physical and financial assets, to understand the poor's economic strategies in the face of crises and opportunities. One key conclusion has been that not all assets required for running a business are readily available to the poor (Verrest, 2012). Here too, however, little attention has been paid to the structural causes of such exclusion processes (Da Corta, 2011, pg. 26-27). Arguably, the concept of 'social capital' suffers from a similar weakness. It is seen as a way to take social context into account and to explain market failures. But social capital is too often taken as an individual rather than a collective resource (Harriss, 2006). These approaches theorise only on the level of the individual but fail to undertake a deeper structural causal analysis of how markets really work.

Macro-economic approaches, like those of Davis (2006), Karnani (2011) and Bateman (2010) offer a more convincing understanding of the limits of self-employment. They situate local markets within a broader analysis of present-day accumulation models. However, they pay little attention to the social regulation of markets and the unequal capacity of specific groups to influence how markets operate. While the issue of power is too often ignored in development studies, a long tradition within political economics has tried to understand the causal mechanisms behind the hierarchical features of local markets. Such literature inspired by a Marxist approach has looked at how production forces and the social relations behind production, mostly defined in terms of the ownership and control of the means of production, determine processes of accumulation, exploitation and the complex linkages between production and distribution systems ${ }^{5}$. It does not approach small producers and entrepreneurs, or 'petty commodity

\footnotetext{
${ }^{5}$ See for instance Moser (1978), Williams (1982). For India, see Bhaduri (1986); Bharadwaj (1985); Harriss (1982),
} Hale (1978). 
producers' as they are often referred to, as isolated entities. It instead considers their position within the wider economy. Within the economic hierarchy, such producers are clearly confined to poorly profitable activities and doomed to 'self-exploitation'. This is due to their highly asymmetric bargaining power on various markets, as a result of discriminative, exploitative and monopolistic sub-contracting positions, and a lack of influence over regulatory institutions. Petty commodity producers also face discriminatory social regulation. While they can mostly evade legal supervision and taxes, various social institutions such as gender, caste, ethnicity, religion, age and place, have a determining impact. This in turn affects a vast array of factors, including occupations, recruitment, apprenticeships, pricing, the design and enforcement of contracts, conflict resolution, license or public contract deliveries, credit access, land, space and energy. (Harriss-White 2010, 2012).

It could be argued that modernization and globalization are bringing about the decline of traditional aspects of hierarchy and social discrimination. Recent work has however shown this not to be the case. So-called 'traditional' institutions may be evolving, but they still influence accumulation processes, structures and opportunities (Harriss-White, 2003). This is clear in terms of gender with a great amount of evidence from India and elsewhere that gender and patriarchal norms still determine occupations, value chain positions, access to various sorts of resources and both individual and collective bargaining ${ }^{6}$. But it is also clear for other marginalized groups as can be seen in the large body of evidence garnered by Barbara Harriss-White on Indian labour markets (2003), or in more specific work on Dalit entrepreneurship (Prakash, 2010). As will be shown in this paper, looking at how real markets operate offers a better understanding of microcredit failure in terms of job creation.

\section{Methodology}

This paper uses multivariate analyses of household surveys together with qualitative analysis of how markets operate. Its qualitative and quantitative insights should be seen as complementary ways to establish causalities and understand underlying processes (Rao and Woolcock, 2003). Our initial qualitative analysis allowed us to generate the hypotheses that caste and gender influence both the chance of being self-employed and the type of self-employment. Statistical data and econometric analyses were then applied to establish correlations and isolate the role of specific variables on self-employment. We then turned to further qualitative analysis to better understand the processes underlying these correlations. The results are part of a long-term research program on labour and finance set in various districts in north and coastal rural Tamil Nadu. The program has been running since 2003. It brings together researchers

\footnotetext{
${ }^{6}$ In India, see for instance Unni (2008) for a general overview, Mezzadri (2012) for the garment industry, Bhowmik and Saha (2012) for street vendors, Sudarshan et al. (2007) for home-based workers.
} 
from different backgrounds, some of whom live on site. It draws on a wide range of methods, including semi-directive interviews, case studies, close analyses of villages, value chains and markets and household surveys. We have spent considerable time in the villages and in the markets, observing transactions, discussing informally with vendors, buyers, wholesalers and financers. Fieldwork was done in various sectors including transportation, weaving, and tailoring, which are the most common crafts for local entrepreneurs. We undertook detailed case studies of around forty entrepreneurs who run different sizes of businesses in different sectors.

The main objective of our ongoing interviews and informal discussions was to understand the paths these entrepreneurs had followed. How did they operate their businesses and what was their position within their particular value chain? We also spent time at strategic sites such as the tea stalls popular with local entrepreneurs, where many transactions and discussions happen. Most of the data we present here comes from our observation of how real markets operate.

Our quantitative data comes from a household survey done in March 2010 on 405 households. The main objective was to quantify the diversity of labour and financial relationships of all household members, and the type of underlying nature of their social relationships. We took a sample of households from ten villages on the border of two districts (Villupuram and Cuddalore districts). Households and villages were randomly selected, using a stratified sample based on caste and location in terms of water availability and distance to town.

\section{Context}

The studied zone is economically dynamic featuring a large proportion of irrigated agriculture, two industrial towns (Neyveli and Cuddalore) and a regional business centre (Panruti) ${ }^{7}$. A lack of economic dynamism cannot therefore account for the challenges its small businesspeople face. As elsewhere in Tamil Nadu and India, caste remains a fundamental factor in social, economic, ritualistic and political life. Caste here is inherited through one's birth group. It is characterized by endogamy, the rules of commensality and hierarchy, the latter still being associated with ritual dirt and pollution. Vanniyars and Paraiyars are the two major local groups across the region. Vanniyars are a farming caste with a low ritual rank, but in the villages we studied, as in many places in northeast Tamil Nadu, they control much of the land and are politically dominant ${ }^{8}$. Paraiyars are one of the three major Dalit (ex-untouchable) communities in Tamil Nadu. They are particularly well-established in the north of the state. There are also few Arunthathiyars among the Dalits. The upper castes of the local hierarchy are the Mudaliyars, Naidus,

\footnotetext{
${ }^{7}$ For more details on the region under study, see Guérin et al. (2014)

${ }^{8}$ There are also a few Gramanis, Navithars, Nattars, Kulalars and Asarais, who have a similar position in the caste hierarchy.
} 
Reddiyars and Settus, who account for only a small proportion of the village population. They have mostly moved away from the villages to nearby towns, adopting urban jobs and lifestyles. Christians and Muslims are a minority in the area.

The region is financially dynamic, with microcredit just one option among many. Both men and women juggle a wide range of borrowing sources. These include private moneylenders, pawnbrokers, traders, suppliers, employers, shopkeepers, family and friends. Banks play only a minor role (Guérin et al., 2013b). There are three microcredit providers in the area. One is an NGO, while the two others are nonbanking financial institutions. Microloans are delivered exclusively through self-help-groups (SHG) which is the most common form of microcredit in India (Garikipati, 2008; Kalpana, 2011). SHGs have fifteen to twenty members, mostly women who circulate money within the group, and who are eligible for external loans. Women can also apply for much larger individual loans than typical SHG loans. While the provider chooses the beneficiaries, the group still plays an intermediary role and remains responsible for the repayments. The area's three microcredit organizations all have the clear goal of promoting incomegenerating activities.

\section{The chance of being self-employed}

This section assesses whether access to microcredit statistically influences the chance of being selfemployed. We also analyse whether caste and gender statistically influence that chance. Table 1 shows rates of self-employment on a household (panel A) and individual level (panel B) for the total sample, as well as for men versus women, and Dalits versus higher castes. T-tests and Pearson $\chi^{2}$-statistics assert whether the observed gender and caste-differences are statistically significant.

The unit of analysis for Panel A is the household, which is considered self-employed when the household has at least one self-employed member. $37 \%$ of all households prove to have at least one self-employed member. This rate is significantly higher for mid and upper castes (45\%) than Dalits (28\%). In Panel B, an individual is considered self-employed if he or she is the main initiator of a business. It shows that $9 \%$ of all people are self-employed, but this rate is significantly lower for women (3\%) than men (14\%). It is also significantly lower for Dalits (6\%) than for mid and upper castes (12\%).

\section{$<$ Insert table $1>$}

Table 2 presents LOGIT analyses where the chance of being self-employed is regressed against gender and caste, controlling for individual characteristics (age and education) and household characteristics (size of household, social networks and land ownership). The different columns test for the inclusion of 
additional geographical controls to account for location-specific differences in self-employment. The results broadly confirm the descriptive statistics. Women and Dalits have a significantly lower chance of being self-employed after controlling for individual, household and geographical factors. The F-statistics and $\mathrm{R}^{2}$-statistics are generally satisfactory and improve when additional geographical controls are taken up.

\section{$<$ Insert table 2>}

Our qualitative work gives an additional insight into these self-employment statistics. Our fieldwork showed that gender and caste largely determine the nature of networks which may or may not be able to deliver the skills and resources for running a business successfully. For instance, they are determining factors for getting accurate market information, obtaining orders and supplies, meeting credit needs, and arranging labour supplies. This goes for both new and longer-standing businesses. Caste and gender also influence existing social norms and are important drivers within the local markets. Restrictions on women's physical mobility and contact with strangers are a major obstacle to running a business, for instance. The most important caste barriers reflect two key hierarchical features. These are the segregated division of labour, and 'untouchability'. They have both changed over time and their continued role in the caste system has been subject to much debate but both clearly still considerably influence village life, social relationships and occupations in this region. We will address this more in depth in the next section when discussing the types of businesses in which Dalits are active.

In Table 3, we analyse whether access to microcredit is an important factor in starting up a business. In the first three columns we add a dummy that is 1 if the family has access to microcredit (dumMICROCREDIT) as an extra explanatory variable to the previous LOGIT analyses. As can be seen, the coefficient on the dummy is not significant in any of the specifications, suggesting that the chance of being self-employed is unaffected by access to microcredit. In the next three columns we model access to microcredit (dumMICROCREDIT) as an interaction-effect with women and lower castes. This interaction-term analyses whether lower self-employment levels among women and lower castes are influenced by access to microcredit. In other words, if women and Dalits would have access to microcredit, would they still have lower levels of self-employment than their male and upper caste counterparts? As can be seen, none of the coefficients on the interaction-terms are statistically significant suggesting that access to microcredit does not alleviate the lower self-employment figures of women and lower castes. The main conclusion of Table 3 is that access to microcredit plays virtually no role in promoting self-employment in our South Indian context. 
$<$ Insert table 3>

\section{Type of business: gender and caste matters}

This section focuses on the businesses that are initiated analysing whether gender and caste have an impact on criteria such as business type, age, size of initial investment, return and regularity of return, and business expansion. The differences found are again further explained using qualitative insights. Table 4 shows the differences between men and women, and Dalits and mid and upper castes, across several business characteristics. Mann-Whitney, Pearson $\chi^{2}$ and t-statistics test whether the observed differences are statistically significant.

First, we look at the type of business initiated. Following a standard typology of small businesses, we divide our sample into three main types of business: 'craftsmen' account for slightly half of the whole sample (45.9\%), 'service providers' and 'vendors/traders' represent slightly more than one quarter each ( $27.1 \%$ and $27.1 \%$ respectively). As the table shows, businesses started by women have a similar typebreakdown to those started by men. Dalits, however, appear to operate in quite specific sectors. They are more frequently vendors (50\% as opposed to $16.24 \%$ for non-Dalits) and less frequently craftsmen ( $28.57 \%$ as opposed to $56.41 \%$ for non-Dalits). They are slightly under-represented in services $(21.43 \%$ as opposed to $27.35 \%$ ), the observed differences being statistically significant.

Next, we look at the age of businesses. Some lines of work have been passed down among generations, while others are more recent. There is no significant difference based on gender. For caste, by contrast, businesses started by Dalits are significantly younger than those started by higher castes. Dalit businesses had been running for 10.17 years on average, as opposed to 15.76 years for middle and upper castes.

Finally, we look at the size and success rates of businesses measured in terms of initial investment size, annual income, regularity of income and growth in staff members ${ }^{9}$. Here we find that both Dalits and women are confined to smaller and less profitable activities. Both women and Dalits have significantly lower initial investment amounts. Across the whole sample, the average amount invested is 70,000 $\mathrm{INR}^{10}$. This ranges widely from 150 INR to 600,000 INR, with a median value of 15,000 INR. Around half of the respondents invested 10,000 INR or less, while $27.93 \%$ invested between 10,000 and 200,000 INR while the remainder (18.99\%) invested over 200,000 INR. The average amount invested by women is almost

\footnotetext{
${ }^{9}$ Collecting figures on small businesses is very challenging as many of them do not keep proper accounts. A number of precautions were taken here to ensure reliable figures: good knowledge of local prices and the operating costs of the most common businesses, an interview guide adapted for local contexts and local terminology, and the option of holding several interviews.

${ }^{10}$ At the time of the survey, 1 INR $=0,0167$ euros.
} 
three times lower than for men (27,810 INR as opposed to 78,679 INR) and the differences between median is even greater (4,000 INR as opposed to 19,000 INR). The average amount invested by Dalits is approximately half the amount of non-Dalits (41,534 INR as opposed 84,690 INR).

Labour force expansion is another indicator of business size and success. In our sample, $38.28 \%$ of businesses have one employee besides the owner. We do not find any caste differences, but gender seems to matter: women are less likely to have employees ( $16.67 \%$ as opposed to $42.75 \%$ for men). In terms of income, both women and Dalits earn significantly less than their male and upper/mid caste counterparts. Estimates of annual income indicate that women earn on average 34,555 INR, as opposed to 51,627 INR for men. Dalits earn on average 30,161 INR as opposed to 58,205 for non-Dalits, which is roughly half as much.

$<$ Insert table 4>

We again turn to qualitative insights to enrich our understanding of the statistics observed. We will discuss caste and gender separately as they tend to have distinct influences on the type, size and success of businesses initiated.

\section{Caste-related business features}

First, traditional caste-based activities still continue. Just over a third of the entrepreneurs in our sample call their activity 'caste-based'. For instance, in the category 'craftsmen', 59\% of entrepreneurs do traditional handicraft (weaving, pottery, clay or wood toymaking, carpentry, shoemaking), each of which is associated with a particular caste. The remaining $41 \%$ of craftsmen are modern artisans such as masons, electricians and mechanics, where both Dalits and non-Dalits are found. Other particular services such as washing, ironing, drumming and horoscopes are only carried out by Dalits.

Modern sector occupations are supposed to be caste-free (Fuller, 2003), but in practice many modern activities are often a continuation of previous caste-based activities (Harriss-White, 2003, pg. 177). From the various interviews we held with traders and buyers, across all castes, it appears that Dalits are virtually banned from sectors related to food and clothing. These are two types of goods with high symbolic connotations. Dalits only start out in these sectors with a very restricted clientele within their own caste. There are some rare exceptions, but most self-employed Dalits only have non-Dalit customers for traditionally caste-based, socially degrading and/or physically demanding jobs.

The food retail-industry is a first example. This sector is monopolized by non-Dalits for several reasons. The food trade had traditionally been restricted to castes of merchants such as Chettiars and Nadars, who 
even today control much of the sector for reasons of ideology (untouchability), reputation and network. They still have a quasi- monopoly on highly symbolic products such as oil. Vanniars, for instance, are one of the dominant castes in the region and often have small grocery stores, but very few sell oil. 'Untouchability' bans Dalits from selling food to non-Dalits. We found a few exceptions in small towns, but in the villages this would virtually be unthinkable. Moreover, many Dalits prefer to buy food products with high symbolic value, such as oil, milk or rice, from non-Dalits. Reputation is probably critical here. Many products are sold by weight and are not pre-packaged, which means that shopkeepers are mostly valued for their honesty. Chettiars and Nadars have a solid reputation for reliability. Dalits often accuse their caste-fellows of cheating on weight, which, we were told several times, would be the only way for them to gain profit margin.

Accessing networks and resources through caste is also central. The entire value chain, from wholesalers to retailers, is controlled by Chettiars, Nadars and to some extent Vanniars. This gives them privileged access to quality products at preferential rates, often on credit without additional cost. Repayments are flexible and are often based on sales rather than pre-fixed instalments. Shops are frequently part of family networks, and there are regular transfers of goods to avoid stock shortages. Where competition is strong, retailers can afford to have lower prices because profitability of the whole value chain is what counts. Sale on credit is a must-have in terms of competitiveness and client loyalty, but requires sound financial bedrock. In the villages, a few Dalit-run grocery shops can be found, but they are confined to Dalit settlements and only sell to Dalits. There is very little stock on display, and profitability is lower. Many have had to shut down because of too many default payments, too few clients, or purchases on credit straining their profitability.

Tailoring is another interesting example. Tailors face strong competition from manufactured products. Even poor people in local populations want to buy modern clothing. Women want nylon saris bought in Chennai, and not locally produced cotton blouses. Young men no longer want dhotis, but blue jeans. At the same time, demand for tailor-made clothes for special occasions is increasing. Children are now more likely to attend school, from the early years to the end of secondary school and they frequently wear tailormade uniforms. Religious festivals and family celebrations are growing in scale and there is a big market for tailors through demand for wedding gifts and clothing for the event. Tailors are also often approached to recycle old clothes. Here too, the market is highly segmented. Non-Dalits refuse to touch clothes handled by the lowest castes. Moreover, experience is key to high quality work. Most tailors start out as apprentices or employees, something which Dalits, lacking networks and contacts, cannot do. Some NGOs offer training, but it is too brief for participants to gain real knowledge and know-how. Some try to 
help women to access markets, but all the cases we encountered were a failure which is why there are virtually no Dalit tailors.

Finally, 'transportation services' are a good illustration of the continuity between traditional and modern activities. At first glance, caste may not seem an issue. But looking at who transports what clearly shows strong segmentation. Non-Dalits transport passengers, while Dalits transport goods. The former requires personal links, the latter physical strength. Traditionally, Dalits have transported mostly agricultural goods using bullock carts. These have been replaced by small motor vehicles. Many financial companies sell them on credit to Dalits through leasing contracts, which prevent any risk, both for creditors and debtors. But Dalits still stick to transporting small quantities over short distances. Long-distance transport, which is more lucrative, is monopolized by the middle and upper castes. Dalits do also work in this area, but only as daily labourers for physically demanding loading and unloading tasks.

Collective organizations and corporatism are another key difference between Dalits and non-Dalits. We found that association membership has a significant influence on the chances of starting a business. This is not surprising since trade is highly embedded in social relations and patronage still the most common way to access resources. But what counts more than having individual or household-level networks is their regulatory role on a more global level (Harriss-White 2003, pg. 184-193). Networks facilitate access to suppliers and clients. They can also defend collective interests and privileges, and organize markets. The transportation industry is a good example here too. The strong segmentation (with Dalits specializing in short distances and non-Dalits in long distances) is closely linked to non-Dalit corporatism. Non-Dalits use their strong alliances with public administration, where they are also over-represented, to manage licensing and procurement. They spend a lot of time in places such as tea stalls or their own shops, where flows of information circulate. They cooperate to fix prices: the market structure here is much closer to collusion than competition. They lend to each other (bank loans represent only a meagre share of debt). They help each other out, for example when one of them is unable to supply an order on time. Dalits by contrast are usually poorly organized. Most buy their vehicle on credit from a financial company and face strong pressure for repayment. The market for short-distance transport is overcrowded highly competitive and therefore not lucrative. Small transporters may help each other out from time to time, but do not engage in any collective action and have very little control over pricing. They do not need licences, but are often harassed by public officials to pay taxes, while the vast majority of big transporters operate outside any legal or fiscal restrictions.

\section{Gender}


As discussed above pure female entrepreneurship remains marginal. Given that the social norms relegate women to a state of dependency, female entrepreneurship goes against the social norm. As we discussed earlier, patriarchal norms greatly restrict female labour by controlling women's mobility. Women who are too mobile suffer damage to their reputation and honour, especially among higher castes. Domestic obligations, which women still mostly bear, are also important. In other parts of India, mobility restrictions on women have promoted home-based forms of self-employment such as sewing and stitching for the garment industry, rolling beedi or incense sticks. There are no such industries in our two districts, however. Agriculture is thus the most common source of employment for women and daily agricultural wage labour has become mostly women's work in recent decades. Dalit women face less restrictive norms on their mobility, but have just as many domestic obligations. They also face additional obstacles due to being Dalit.

Women's low autonomy to run businesses is why the few who do take business initiatives go into similar sectors to men. There are more gendered divisions in certain categories, such as trade and trade services. In retail, for example, women typically sell low-value products, mostly or exclusively for women, from home or door-to-door in the villages. These include food, sarees, imitation jewellery and cosmetics. Sometimes, male family members (husbands, sons, brothers and fathers) are involved in the supply process. This allows women to stay at home, in respect of social norms. Some women take care of the supply themselves but this requires some freedom of movement. This is more common with older women or middle and upper caste widows. Dalit women face fewer restrictions but this remains a very relative freedom. Women do not escape the rules of commensality, either, and it is rare for Dalit women to sell to non-Dalit women.

As such, it is hardly surprising that women run smaller businesses than men (as we have seen above, their initial investment is three times lower) and that they bring in a limited income. This is partly a matter of access to capital and assets (Garikipati, 2008). The law stipulates for daughters to inherit equally, but this is not the case in practice. Girls receive a dowry at their wedding which is supposed to compensate them for their lack of an inheritance. This usually includes gold and furniture, or sometimes small pieces of land, and increasingly, motorcycles. But all this is often seen as collective property (and even exclusively male property for motorbikes). Women are in a poor position to build up savings from their wage incomes, which are very low.

Irrespective of 'access to capital', the very low level of opportunities open to women is the major reason why their businesses remain small. The women all have the same questions: what should be sold, where and to whom? In our study area, the three microcredit organizations provide additional services for 
entrepreneurship such as training and assistance to access markets (for instance for tailoring). But these efforts have failed to remove the multiple social barriers women face.

As a result, microcredit in our study region has largely failed to promote income-generating activities for women. In our sample, $38 \%$ of households received at least one microcredit in the year prior to the survey and women have been the most common beneficiaries by far. Less than $10 \%$ of these loans, however, has been used for economic investment. Only $7.9 \%$ is used for agriculture, and $2 \%$ for non-farm investment. Microloans are mostly used for daily expenses, health, past debt repayment, education, housing and ceremonies. When questioned, neither male nor female entrepreneurs mentioned microcredit as a source of finance.

Inadequate microloan conditions are probably one cause for such failure. Microcredit is often too small (around 10,000 INR on average) and inflexible to finance a sustainable income-generating activity. Monthly instalments are badly suited to the irregularity and seasonality of many small businesses. According to our survey, businesses started by men and women are partly funded by savings and inheritances, and partly through debt. But more flexible sources also come into play. These include relatives, local private moneylenders, traders and suppliers. In very rare cases, banks or financial companies are a further source. One of the major advantages middle and upper caste businessmen enjoy is ready access to cheap and flexible cash from their peers, as we have seen above for the transport sector. In this market, financial practices are also embedded within local social institutions that are much more efficient than microcredit, but largely beyond the reach of marginalised categories (Guérin et al. 2013b).

\section{Conclusions and discussion}

The microcredit movement relies heavily on the idea that every poor person has the potential to become a successful entrepreneur. By helping the poor access credit, the untapped entrepreneurial spirit of the poor is expected to emerge, and economic development to follow. From this rather narrow perspective, the ability to start a business is mainly a matter of skills, financial resources, managerial capacity and access to basic infrastructure.

Some scholars, however, express concerns about this 'entrepreneurial capability' of the poor. They highlight either microeconomic factors (such as Banerjee and Duflo, 2011) or macroeconomic factors (such as Bateman, 2011; Servet 2006, 2010) to argue that the poor have a very low chance of engaging in a successful income-generating activity. Their arguments have been supported by empirical studies showing that microfinance is often used for consumption and that there are many difficulties involved in the poor becoming successful entrepreneurs (Morduch, 2013; Perry, 2002; Rahman, 1999; Elyachar, 2006). 
This paper on rural South India combines quantitative analysis and qualitative insights to explore a further impediment that marginalized categories face in developing an income-generating activity, namely the social barriers of gender and caste. In the Tamil Nadu region, women and Dalits have a significantly lower chance of being self-employed when controlling for individual and household characteristics. Furthermore, we find no significant statistical relation between access to microcredit and the chance of being self-employed. Qualitative analyses suggest that social regulation and norms on caste and gender shape local markets and determine who can produce or sell what, to whom at what price.

We also find that women and Dalits when they are able to produce or sell on their own, tend to be restricted to certain activities and therefore stick to smaller and less profitable businesses. While they are officially self-employed, they are socially restricted to particular low-income sectors with little or no growth prospects. Social norms restrict their networks which hinder their access to suppliers, clients, finance, administrative support, and other necessary resources.

Our analysis reinforces the idea that funding is just one of many factors for successful entrepreneurship. Both Dalits and women have a significantly lower initial investment. They are likely to have lower amounts to invest and greater difficulties in accessing credit. They suffer from discrimination from both formal and informal lenders (Guérin et al., 2013b). While 'untouchability' is less of a concern than it historically was in India, patriarchy remains a particularly pressing issue. We ultimately find the market to be very highly segmented and unequal.

Access to capital will not alleviate the many social barriers women and Dalits face. This does not mean microcredit is of no use, because it may help to bridge shortfalls in income, as various studies have suggested (Patole and Sinha, 2005) ${ }^{11}$. Additionally, as Kalpana's work on a different region of Tamil Nadu has highlighted, women may use microcredit groups as a 'space of socialisation' to avoid rather than fight patriarchal norms (Kalpana, 2011). But the fact remains that microcredit is ineffective as far as job creation is concerned.

We believe this paper makes a number of important contributions of interest to research and policy. From a theoretical perspective, it shows the extent to which markets are socially structured and regulated. The most vulnerable groups, such as women and Dalits, are the least likely to successfully start up a business because of the persistent social regulations that shape local markets. The norms underlying social regulations are not fixed over time and are constantly changing but still considerably restrict opportunities for marginalized categories. While our findings apply to a very specific context, they echo a long-standing school of research that approaches markets as institutions within larger social and political systems. They

\footnotetext{
${ }^{11}$ Even this, however, remains controversial (Garikipati et al., 2014) especially when supply exceeds local absorption capacities leading to over-indebtedness, as has been seen in Andhra Pradesh (Taylor, 2011).
} 
draw on the work of authors like Weber (on how markets are shaped through struggles and power constellations) (Weber, 1978, pg. 108), Polanyi (on how markets are embedded in social interactions and connected to other principles of exchange) (Polanyi, 1977, chapter 1), and Bourdieu (on how the 'field' in which markets are situated dominates their dynamics) (Bourdieu, 2000). This strand of literature approaches markets as consisting of social relationships between individuals who have highly unequal material, cultural, social and symbolic resources. Only in-depth empirical studies can show the specific manifestation of market structures within a specific context (Morvant et al., 2014). But as much recent research evidence has shown, we can reasonably assume that all markets are to a certain degree socially structured $^{12}$. While development policies are increasingly market-based, there is an urgent need to move away from an abstract vision of markets as contracts between equals and to see them as what they really are: socially constructed entities reflecting power relations between individuals with unequal resources.

As far as microcredit policy is concerned, we believe microcredit cannot succeed unless the social regulation of markets is acknowledged. The social, cultural and political barriers women and lower castes face must be substantially alleviated. Given this has not yet happened and the distinctive kinds of businesses that women and lower castes are setting up, it seems likely that microcredit in its current form is strengthening rather than weakening social inequalities. Moreover, microcredit does not currently enhance job-creation and will not do so unless social barriers are alleviated. One central point here concerns the fight against discrimination. In our case study, Dalits and women face high levels of discrimination which exclude them from many activities or condemn them to be stuck at the end of the value chain. This is of course a long-term struggle and calls for action on multiple levels (Mosse, 2010) that are beyond the scope of this paper, but cannot be ignored. Promoting self-employment for the discriminated segments of societies is simply destined to fail if one ignores the underlying social causes of such discrimination. With particular regards to gender, and far beyond the Indian case, empirical evidence has indicated that the microfinance industry's focus on women by no means shows that it takes gender discrimination seriously (Agier and Szafarz, 2013; D’Espallier et al., 2011; Johnson, 2013).

On a more abstract note, one could even challenge policies that promote self-employment altogether. Some people can certainly benefit from microcredit but the number of people among the poor who are willing and able to run a sustainable business is undoubtedly much more limited than expected. Not only do self-employment policies such as microcredit have a limited impact, but they may also reinforce considerable unfairness within capitalist accumulation. They promote the individualization of risk and 'entrepreneurs of the self' which is at the core of current neoliberal policies (Rose, 1999). Microcredit has taken highly diverse approaches, paths and ideologies, so the question of whether it is 'good' or 'bad' is

\footnotetext{
${ }^{12}$ For a review, see Swedberg (2003). Even Wall Street markets are socially regulated, see for instance Ho (2009).
} 
not necessarily helpful (Armendáriz and Labie, 2011). Nevertheless, the microcredit industry's growing commercialization, 'financialisation', and increasingly close links to global capital have raised serious questions over its ethics (Hudon and Sandberg, 2013) and its effective capacity to promote redistribution, justice and poverty alleviation (Augsburg and Fouillet, 2010; Bateman, 2010; Fernando, 2006; Guérin et al., 2013a; Roy, 2010). Several ethnographies have shown how some microcredit programmes with a primary focus on loan disbursement and repayment can discipline or even dispossess the poor (Elyachar, 2006). Women are particularly affected (Karim, 2011; Rankin, 2002).

Despite recent over-indebtedness crises (Guérin et al., 2013a), the 'financialisation' of microcredit continues to spread. The very purpose of microfinance should be to spread risk and this is a key condition for finance to create wealth and promote redistribution. But current 'financialisation processes' merely serve to protect lenders and shift the risk disproportionately onto the poor. As Aitken (2013) argues, the microcredit industry has adopted evaluation, securitization and intermediation tools to ensure lender security, while transferring the risks of global capital onto the borrowers. More importantly, one can question the legitimacy of development policies driven by a 'regime of indebtedness' (Dienst, 2011). They drain already low and irregular labour income, and subordinate ordinary people to the rules of capital (Graeber, 2011; Lazzaroto, 2011). When local populations are already highly indebted, as it is the case here (Guérin et al., 2013b; Morvant et al., 2015), is microcredit part of the solution, or the problem?

It is crucial to rethink microcredit in terms of the much broader goal of reforming finance, markets, local economies and their links to the global system. This calls for action on various levels. On the local level, its means helping small entrepreneurs who face discrimination based on their caste, gender, ethnicity, religion. They need the means to organize themselves to influence the design of quality standards, the fixation of prices, the winning of contracts from the public sector, and so on. This will allow them to access markets and achieve a stronger position within the value chain. It also means helping women to access property, reduce their domestic burdens and the constraints on their physical mobility. On a wider level, it means rethinking microcredit less as a way to give the poor access to finance in a context driven by debt and over-indebtedness, and more as a way to enhance collective empowerment of marginalized groups and the revitalization of marginalized local economies. Rather than inserting individuals into global value chains, this means creating local networks by linking up producers, service providers and local consumers (Bateman, 2010, pg. 167-200; França Filho et al., 2013). This needs real determination to fight discrimination and to change the rules of the game. It will also ultimately need full recognition of the rights of marginalized communities, so they can speak for themselves and get collectively organised, in order to influence how markets are shaped and structured. 


\section{References}

Agier, I., A. Szafarz. (2013) Microfinance and Gender: Is There a Glass Ceiling on Loan Size? World Development 42: 165-181.

Aitken, R. (2013), The Financialization of Micro-Credit. Development and Change, 44: 473-499.

Armendáriz, B. and Labie, M. (eds) (2011) Handbook of Microfinance, World Scientific Publishing: London and Singapore.

Augsburg B. and Fouillet C. (2010) Profit Empowerment: The Microfinance Institution's Mission Drift. Perspectives on Global Development and Technology [Special Issue: Microfinance and Institutions], 9 (3-4): 327-355.

Banerjee, A.V. and Duflo, E., (2011) Poor economics: a radical rethinking of the way to fight global poverty. PublicAffairs: New York.

Bateman, M., (2010) Why doesn't microfinance work: the destructive rise of local neoliberalism. Zedbooks: New York.

Berner, E., Gomez, G., and Knorringa, P. (2012) Helping a large number of people become a little less poor: The logic of survival entrepreneurs, European Journal of Development Research, 24(3): 382396.

Bharadwaj, K. (1985) A View on Commercialisation in Indian Agriculture and the Development of Capitalism, Journal of Peasant Studies, 12(1): 7-25.

Bhaduri A. (1986) Forced commerce and agrarian growth, World Development, 14(2): 267-272.

Bhowmik S. and Saha (2012) Street Vending in Ten Cities in India, Report for the National Association of Street Vendors of India, School of Management and Labour Studies Tata Institute of Social Sciences.

Bourdieu P. (2000), Les Structures sociales de l'économie, Paris : Seuil.

Cling J.P., Lagrée S., Razafindrakoto M., Roubaud F. (eds.) (2015) The informal economy in developing countries. Oxon : Routledge.

Da Corta L. (2011) The political economy of agrarian change: dinosaur or phoenix? in HarrissWhite B, Heyer J. (eds) The Political Economy of Development: Africa and South Asia Compared, London: Routledge, pp. 18-46.

Davis M. (2006) Planet of Slums, London: Verso.

De Mel S., D. McKenzie, and C.Woodruff (2010) Who Are the Microenterprise Owners? Evidence from Sri Lanka on Tokman v. de Soto, in J. Lerner and A. Schoar (eds.), International Differences in Entrepreneurship, Chicago: Chicago University Press, pp. 63-87.

De Soto F. (2003) The mystery of capital. Why capitalism triumphs in the West and fails everywhere else, New-York: Basic Books.

D'Espallier B. Guérin I. Mersland R. (2011) Women and repayment in microfinance. A global analysis. World Development, 39(5): 758-772.

Dienst R. (2011) The Bonds of Debt, London and New York: Verso.

Elyachar J. (2006) Markets of dispossession: NGOs, economic development and the state in Cairo, Durham, NC: Duke University Press.

Fernando J. (2006) (ed) Microfinance. Perils and Prospects, Routledge: Londres.

França Filho G. C., Scalfoni Rigo A. et Torres Silva Jr. J., (2013) Microcredit Policies in Brazil : An Analysis of Community Development Banks, in : I. Hillenkamp, F. Lapeyre et A. Lemaitre, (éd.), Securing Livelihoods. Informal Economy Practices and Institutions, Oxford: Oxford University Press, p. 115-132.

Fuller C. J. (2003) Caste in Daas V. (ed) The Oxford India companion to sociology and social anthropology, New-Delhi: Oxford University Press, pp. 477-201.

Garikipati S. Agier I. Guérin I. and Szafarz A., (2014) The Cost of Empowerment: Multiple Sources of Women's Debt in Rural India, Working Papers CEB 14-007, ULB - Université Libre de Bruxelles. 
Garikipati, S. (2008) The impact of lending to women on household vulnerability and women's empowerment: evidence from India, World Development 36(12): 2620-2642.

Graeber D. (2011) Debt : The First 5,000 years, Brooklyn NY : Melville House, 534 p.

Grimm M., Knorringa, P., and Lay, J. (2012) Constrained gazelles: High potentials in West

Africa's informal economy. World Development, 40(7): 1352-1368.

Guérin I. D’Espallier B. Venkatasubramanian G. (2013b) G. Debt in Rural South India: Fragmentation, Social Regulation and Discrimination, Journal of Development Studies, 49(9): $\mu$ $1155-1171$.

Guérin I. Michiels S. Venkatasubramanian G. (2014) Labour in contemporary South India, in Heyer J. Harriss-White B. (eds) Capitalism in Development, London: Routledge, pp. 118-136.

Guérin I. Morvant-Roux S. Villarreal M. (eds) (2013a) Microfinance, debt and Over indebtedness.Juggling with money, London: Routledge. $245-275$.

Hale S. (1978) The Politics of Entrepreneurship in Indian Villages, Development end Change, 9:

Harriss J. (1982) Rural development: Theories of peasant economy and agrarian change, London: Hutchinson University Library.

Harriss J. (2006) Power Matters: Essays on Institutions, Politics and Society in India, NewDelhi: Oxford University Press.

Harriss-White B. (2003), India Working. Essays on Society and Economy, Cambridge University Press, Cambridge.

Harriss-White B. (2010) Globalization, The Financial Crisis and Petty Production in India's Socially Regulated Informal Economy, Global Labour Journal: 1(1): 152-177.

Harriss-White B, Heyer J. (eds) (2010) The Political Economy of Development: Africa and South Asia Compared, London: Routledge.

Harriss-White B. (2012) Capitalism and the Common Man: Peasants and Petty Production in Africa and South Asia, Agrarian South: Journal of Political Economy, 1(2): 109-160.

Hart K. (1973) Informal Income Employment Opportunities and Urban Employment in Ghana, Journal of Modern African Studies II(1): 61-89.

Ho K. (2009) Liquidated: An ethnography of Wall Street. Durham, NC: Duke University Press

Hudon M. and Sandberg J. (2013) The Ethical Crisis in Microfinance: Issues, Findings, and Implications, Business Ethics Quarterly, 23(4): 561-589

ILO (1972) Employment, Incomes and Equality. A Strategy for Increasing Productive Employment in Kenya, ILO: Geneva.

Johnson, S., (2013) From microfinance to inclusive financial markets: the challenge of social regulation. Oxford Development Studies, 41 (S1), S35-S52.

Kalpana K. (2011) Subverting policy, surviving poverty: women and the SGSY in rural Tamil Nadu, Economic and Political Weekly, Vol - XLVI No. 43, October 22.

Karim L. (2011), Microfinance and Its Discontents. Women in Debt in Bangladesh, Minneapolis: University of Minnesota Press.

Karnani, A (2011), Fighting Poverty Together: Rethinking Strategies for Business, Governments, and Civil Society to Reduce Poverty. New York: Palgrave MacMillan.

Ligthelm, A. A. (2005). Informal retailing through home-based microenterprises: The role of Spaza shops. Development Southern Africa 22(2): 199-214.

Maloney W. F. (2004) Informality revisited, World development, 32(7):1159-1178.

Mezzadri, A. (2012) Reflections on Globalisation and Labour Standards in the Indian Garment Industry: Codes of Conduct Versus 'Codes of Practice' Imposed by the Firm, Global Labour Journal, 3(1): 40-62.

Morduch J. (2013) How microfinance really works? (What new research tells us about), CERMi's $5^{\text {th }}$ Birthday Celebration, Brussels, March 18. 
Morvant-Roux S., Afonso J., Forcella D., Guérin I. (2015) Clients' Financial Fragility without Microcredit Crisis : a Case Study from Dominican Republic, Microfinance in Crisis, Working Paper Series, $\mathrm{n}^{\circ}$ 4, Paris : Université Paris 1 Sorbonne, Institut de recherche pour le développement (IRD).

Morvant-Roux S., Guérin I., Roesch M. Moisseron J.-Y. (2014) Adding value to randomization with qualitative analysis: the case of microcredit in rural Morocco, World Development, 56: 302-312.

Moser C. (1978) Informal sector or petty commodity production: Dualism or dependence in urban development?, World Development, 6 (9-10): 1041-1064.

Mosse D., (2010) A Relational Approach to Durable Poverty, Inequality and Power, Journal of Development Studies, vol. XLVI, nº 7, p. 1156-1178.

National Sample Survey $66^{\text {th }}$ round (2009-2010). Government of India. http://mospi.nic.in/Mospi_New/site/inner.aspx?status=3\&menu_id=31

Lazzarato M., (2011), La fabrique de l'homme endetté. Essai sur la condition néolibérale, Paris : Éditions Amsterdam

Patole M. and Sinha F. (2005) Microfinance and women's empowerment: research approach and findings from an impact assessment of MFIs in India in Guérin and Palier (eds) Microfinance challenges: empowerment or disempowerment of the poor? Pondicherry; French Institute of Pondicherry, pp. 247-257.

Pattenden J. (2010) A neo-liberalisation of civil society? Self-help groups and the labouring class poor in rural south-India, Journal of Peasant Studies 37(3): 485-512.

Perry D. (2002) Microcredit and Women Moneylenders. The Shifting Terrain of Credit in Rural Senegal, Human Organization, vol. LXI, $\mathrm{n}^{\mathrm{o}}$ 1: 30-40.

Polanyi K. (1977) The livelihood of man, New-York/London: Academic Press.

Prahalad C. K. (2004) The fortune at the bottom of the pyramid. Eradicating poverty through profits, Wharton School Publishing

Prakash A. (2010) Dalit entrepreneurs in middle India, in Harriss-White B, Heyer J. (eds) The Political Economy of Development: Africa and South Asia Compared, London: Routledge, pp.291-317.

Rahman A., (1999) Women and Microcredit in Rural Bangladesh: an Anthropological Study of Grameen Bank Lending. Boulder CO: Westview Press.

Rankin K. N. (2002) Social Capital, Microfinance and the Politics of Development, Feminist Economics, vol. VIII, $\mathrm{n}^{\mathrm{o}}$ 1: 1-24.

Rao, S. (2008) Reforms with a female face: gender, liberalization, and economic policy in Andhra Pradesh, India, World Development, 36(7), pp. 1213-1232.

Rao, V. and Woolcock, M. (2003) Integrating qualitative and quantitative approaches in program evaluation in F. J. Bourguignon and L. P. da Silva (Eds.), The Impact of Economic Policies on Poverty and Income Distribution: Evaluation Techniques and Tools, New York: Oxford University Press, pp. 165190.

Rose N. (1999) Powers of freedom. Reframing political thought, Cambridge: Cambridge University Press.

Roy A. (2010) Poverty capital. Microfinance and the making of development, London/New-York: Routledge.

Servet, J.-M. (2006) Banquiers aux pieds nus : La microfinance, Paris: Odile Jacob.

Servet, J.-M. (2010), Microcredit in : Keith H., J.-L Laville, A. D. Cattani (ed.), The Human Economy, Boston/Cambridge/Oxford, Polity Press, p. 130-141

Sudarshan R. M., Venkataraman S., Bhandari L. (2007) Subcontracted Homework in India: a Case Study of Three Sectors in Mehrota S. and Biggeri M. (eds) Asian Informal Workers: Global Risks, Local Protection, London and New York: Routledge, pp.

Srivastava R. S. (2012) Changing Employment Conditions of the Indian Workforce and Implications for Decent Work, Global Labour Journal, 3(1): 118-142.

Swedberg R. (2003) Principles of economic sociology, Princeton: Princeton University Press.

Taylor M. (2011), Freedom from Poverty is Not for Free: Rural Development and the Microfinance Crisis in Andhra Pradesh, India », Journal of Agrarian Change, vol. XI, n 4: 484-504. 
Turnham, D., Salomé B.and Schwarz A., (eds.) (1990) The Informal Sector Revisited, Paris: OECD Development Centre.

Unni J. (2008) 'Women Workers in the New Economy', Indian Journal of Labour Economics 52(4): 657-674.

Verrest H. (2012) Rethinking Microentrepreneurship and Business Development Programs: Vulnerability and Ambition in Low-income Urban Caribbean Households, World Development, 47: 5870 .

Weber M. (1978) Economy and Society [1 ${ }^{\text {st }}$ edition 1956], Berkeley, Los Angeles and London: University of California Press

Williams G. (1982) Taking the part of peasants: Rural development in Nigeria and Tanzania in J. Harriss (Ed.), Rural development: Theories of peasant economy and agrarian change, London: Hutchinson University Library, pp. 381-399.

World Bank (2004). World development report 2005: A better investment climate for everyone. Washington, DC: World Bank.

World Bank (2013) World development report 2013. Jobs, Washington, DC: World Bank

Yunus M. (2007) Creating a World Without Poverty: Social Business and the Future of Capitalism, Pretoria: New Africa Press. 
Table 1. Overall self-employment figures

Self-employment statistics on the household-level (panel A) and on the individual level (panel B). Pearson $\chi^{2}$-stats and t-tests assess whether the observed differences are statistically different between women and men / Dalits and higher castes.

\begin{tabular}{llll}
\hline Panel A. Families & All & dalits & mid \& upper caste \\
\hline \# total & 405 & 192 & 212 \\
\# self-employed & 150 & 54 & 95 \\
\% self-employed & $37 \%$ & $28 \%$ & $45 \%$ \\
\# not self-employed & 255 & 138 & 117 \\
\% not self-employed & $63 \%$ & $72 \%$ & $55 \%$ \\
\hline pearson $\boldsymbol{\chi}^{2}$ (dalits vs. mid/up) & $12.05^{* * *}$ & & \\
t-test (dalits vs. mid/up) & $3.515^{* * *}$ & & \\
\hline
\end{tabular}

\begin{tabular}{llllll}
\hline Panel B. Individuals & all & $\begin{array}{l}\text { Gender } \\
\text { men }\end{array}$ & Women & $\begin{array}{l}\text { Caste } \\
\text { dalits }\end{array}$ & mid \& upper caste \\
\hline \# total & 1,929 & 1,007 & 921 & 933 & 995 \\
\# self-employed & 176 & 145 & 30 & 58 & 117 \\
$\%$ self-employed & $9 \%$ & $14 \%$ & $3 \%$ & $6 \%$ & $12 \%$ \\
\# not self-employed & 1,753 & 862 & 891 & 875 & 878 \\
$\%$ not self-employed & $91 \%$ & $86 \%$ & $97 \%$ & $94 \%$ & $82 \%$ \\
\hline pearson $\mathbf{\chi}^{2}$ (men vs. women) & $72.35^{* \star *}$ & & & & \\
pearson $\mathbf{X}^{2}$ (dalits vs. mid/up) & $17.92^{* * *}$ & & & & \\
ttest (men vs. women) & $8.66^{* * *}$ & & & & \\
ttest (dalits vs. mid/up) & $4.25^{\star \star *}$ & & &
\end{tabular}




\section{Table 2. Do women and dalits have a lower chance of being self-employed? A multivariate analysis}

LOGIT-analyses where the dummy self-employed is regressed against gender and caste, controlling for individual characteristics (age, education), household-characteristics (size of $\mathrm{HH}$, social capital in terms of a dummy whether the family is involved in any political, cultural or any other association) as well as geographical controls (accessibility of the village, village dummies). Significance levels based upon robust standard errors. $*, * *$ and $* * *$ report significance at the $10 \%, 5 \%$ and $1 \%$ level.

\begin{tabular}{|c|c|c|c|c|c|c|}
\hline dep var. self-employment $=1$ & (1) & (2) & (3) & (4) & (5) & (6) \\
\hline \multicolumn{7}{|l|}{ variables of interest } \\
\hline dumFEMALE & $-1.58^{\star \star \star}$ & $-1.64^{\star \star \star}$ & & & $-1.60^{\star \star \star}$ & $-1.66^{\star \star \star}$ \\
\hline dumDALIT & & & $-0.62^{\star * *}$ & $-0.39^{\star *}$ & $-0.67^{\star \star *}$ & $-0.45^{\star \star}$ \\
\hline \multicolumn{7}{|l|}{ individual controls } \\
\hline Age & $0.04^{\star \star \star}$ & $0.04^{\star \star \star}$ & $0.05^{\star \star \star}$ & $0.05^{\star \star \star}$ & $0.04^{\star \star \star}$ & $0.04^{\star \star \star}$ \\
\hline dumEDUCATIONHIGH & 0.17 & 0.09 & $0.43^{\star \star}$ & $0.41^{* *}$ & 0.11 & 0.06 \\
\hline \multicolumn{7}{|l|}{ household controls } \\
\hline size of $\mathrm{HH}$ & $-0.17^{\star \star}$ & $-0.16^{\star \star}$ & $-0.16^{\star \star}$ & $-0.16^{\star \star}$ & $-0.15^{\star \star}$ & $-0.16^{\star \star}$ \\
\hline dumASSOCIATION & $0.49^{\star \star \star}$ & $0.34^{*}$ & $0.47^{\star \star \star}$ & $0.35^{\star}$ & $0.49^{* \star}$ & $0.35^{\star}$ \\
\hline dumLANDOWNER & $-0.37^{\star \star}$ & -0.26 & $-0.52^{\star \star \star}$ & $-0.35^{\star}$ & $-0.49^{\star \star *}$ & $-0.33^{*}$ \\
\hline \multicolumn{7}{|l|}{ geographical controls } \\
\hline dumBADACCESS & - & $0.93^{\star \star}$ & - & $0.75^{\star \star}$ & - & $0.93^{\star \star}$ \\
\hline village dummies & no & yes & No & Yes & no & yes \\
\hline \multicolumn{7}{|l|}{ model statistics } \\
\hline \# observations & 1,807 & 1,802 & 1,807 & 1,802 & 1,807 & 1,802 \\
\hline Wald $\chi^{2}$ & $157.70^{\star \star *}$ & $171.59^{\star \star \star}$ & $139.22^{\star \star \star}$ & $159.12^{\star \star \star}$ & $160.63^{* \star *}$ & $175.70^{\star \star \star}$ \\
\hline pseudo $R^{2}$ & 0.14 & 0.19 & 0.10 & 0.14 & 0.16 & 0.20 \\
\hline
\end{tabular}

Source: survey RUME 2010 
Table 3. Microfinance and the chance of being self-employed.

LOGIT-analyses extended with access to microfinance. DumMICROCREDIT is a dummy that is 1 if the household is involved in a microcredit loan. In the first three columns, dumMICROCREDIT is added as an extra explanatory variable investigating whether the chance of being self-employed is statistically influenced by having access to microcredit. In the last three columns, dumMICROCREDIT is modeled as an interaction-term with dumFEMALE and dumDALIT investigating whether the lower self-employment by women and Dalits is influenced by access to microcredit. Significance levels based upon robust standard errors. *** and *** report significance at the $10 \%, 5 \%$ and $1 \%$ level.

\begin{tabular}{|c|c|c|c|c|c|c|}
\hline dep var. self-employment $=1$ & $(1)$ & (2) & (3) & $(4)$ & $(5)$ & (6) \\
\hline dumMICROCREDIT & 0.12 & 0.10 & 0.11 & & & \\
\hline \multicolumn{7}{|l|}{ gender and caste } \\
\hline DUmFEMALE & $-1.64^{* * *}$ & & $-1.65^{\star * *}$ & $-1.89^{* * *}$ & & $-1.95^{* * *}$ \\
\hline DumDALIT & & $-0.39^{* *}$ & $-0.42^{* *}$ & & $-0.38^{*}$ & $-0.37^{*}$ \\
\hline \multicolumn{7}{|l|}{ interactions dumMICROCREDIT } \\
\hline (dumFEMALE * dumMICROCREDIT) & & & & 0.49 & & 0.59 \\
\hline (dumDALIT * dumMICROCREDIT) & & & & & -0.27 & -0.43 \\
\hline \multicolumn{7}{|l|}{ individual controls } \\
\hline Age & $0.04^{* * *}$ & $0.05^{\star * *}$ & $0.04^{* * *}$ & $0.03^{* * *}$ & $0.05^{\star * *}$ & $0.04^{* * *}$ \\
\hline DumEDUCATIONHIGH & 0.10 & $0.42^{* *}$ & 0.07 & 0.08 & $0.40^{* *}$ & 0.05 \\
\hline \multicolumn{7}{|l|}{ household controls } \\
\hline size of $\mathrm{HH}$ & $-0.17^{\star *}$ & $-0.16^{* *}$ & $-0.16^{* *}$ & $-0.17^{\star *}$ & $-0.16^{\star *}$ & $-0.16^{* *}$ \\
\hline DUMASSOCIATION & $0.33^{*}$ & $0.35^{*}$ & $0.34^{*}$ & $0.33^{*}$ & $0.36^{*}$ & $0.34^{*}$ \\
\hline DumLANDOWNER & -0.25 & $-0.34^{*}$ & $-0.32^{*}$ & -0.25 & $-0.35^{\star}$ & $-0.32^{*}$ \\
\hline \multicolumn{7}{|l|}{ geographical controls } \\
\hline DumBADACCESS & $0.89^{\star *}$ & $0.71^{*}$ & $0.88^{* *}$ & $0.89^{* *}$ & $0.78^{* *}$ & $0.91^{* *}$ \\
\hline village dummies & yes & yes & yes & Yes & Yes & yes \\
\hline \multicolumn{7}{|l|}{ model statistics } \\
\hline \# observations & 1802 & 1802 & 1802 & 1802 & 1802 & 1802 \\
\hline Wald $x^{2}$ & $171.95^{\star * *}$ & $158.32^{* * *}$ & $157.72^{\star * *}$ & $170.43^{* * *}$ & $162.67^{\star * *}$ & 175.84 \\
\hline pseudo $\mathrm{R}^{2}$ & 0.19 & 0.14 & 0.20 & 0.20 & 0.14 & 0.20 \\
\hline
\end{tabular}




\section{Table 4. Diversity of self-employment along gender and caste}

Type of self-employment, size of the investment, age, return, regularity and expansion of the businesses analyzed for all businesses, male versus female initiated businesses and dalit versus mid/upper caste initiated businesses. Mann-Whitney is the non-parametric test analyzing whether proportions nominal variables differ along gender and caste, $\mathrm{t}$-tests assert the null that the mean-values are different along caste and gender.

\begin{tabular}{|c|c|c|c|c|c|c|}
\hline diversity of businesses & & $\begin{array}{l}\text { All businesses } \\
n=173\end{array}$ & $\begin{array}{c}\text { female initiated } \\
\qquad n=30\end{array}$ & $\begin{array}{c}\text { male initiated } \\
\qquad n=143\end{array}$ & $\begin{array}{c}\text { dalit initiated } \\
n=58\end{array}$ & $\begin{array}{c}\text { mid/upcaste initiated } \\
n=115\end{array}$ \\
\hline \multirow[t]{5}{*}{ type of business } & Craftsman & $47.40 \%$ & $50.00 \%$ & $46.85 \%$ & $28.57 \%$ & $56.41 \%$ \\
\hline & Service & $25.43 \%$ & $20.00 \%$ & $26.57 \%$ & $21.43 \%$ & $27.35 \%$ \\
\hline & vendor/trader & $27.17 \%$ & $30.00 \%$ & $26.57 \%$ & $50.00 \%$ & $16.24 \%$ \\
\hline & Mann-Whitney stat. (male vs. female) & 0.05 & & & & \\
\hline & Mann-Whitney stat. (dalit vs. mid/up) & $4.36^{* * *}$ & & & & \\
\hline \multirow[t]{6}{*}{ size of initial investment } & Mean & 70,052 & 27,810 & 78,679 & 41,534 & 84,690 \\
\hline & Median & 15,000 & 4,000 & 19,000 & 15,000 & 15,000 \\
\hline & Min & 150 & 500 & 150 & 150 & 500 \\
\hline & Max & 600,000 & 325,000 & 600,000 & 500,000 & 600,000 \\
\hline & ttest (male vs. female) & $1.93^{*}$ & & & & \\
\hline & ttest (dalit vs. mid/up) & $2.06^{* *}$ & & & & \\
\hline \multirow[t]{6}{*}{ age of the business } & Mean & 13.9 & 14.13 & 13.86 & 10.17 & 15.76 \\
\hline & Median & 8 & 8 & 8 & 6.5 & 9 \\
\hline & Min & 1 & 2 & 1 & 1 & 1 \\
\hline & Max & 50 & 40 & 50 & 40 & 50 \\
\hline & ttest (male vs. female) & 0.10 & & & & \\
\hline & ttest (dalit vs. mid/up) & $2.72^{* * *}$ & & & & \\
\hline
\end{tabular}




\begin{tabular}{|c|c|c|c|c|c|c|}
\hline return on the business & Mean & 48,748 & 34,555 & 51,627 & 30,161 & 58,205 \\
\hline \multirow[t]{5}{*}{ (constructed annual income) } & Median & 29,125 & 18,000 & 30,000 & 24,000 & 35,500 \\
\hline & Min & 3,750 & 3,750 & 3,750 & 4,500 & 3,750 \\
\hline & Max & 600,000 & 200,000 & 600,000 & 120,000 & 600,000 \\
\hline & ttest (male vs. female) & $2.25^{*}$ & & & & \\
\hline & ttest (dalit vs. mid/up) & $2.64^{* \star *}$ & & & & \\
\hline \multirow{6}{*}{$\begin{array}{l}\text { regularity on the business } \\
\text { (\# months average income) }\end{array}$} & Mean & 4.15 & 4.93 & 4.00 & 3.91 & 4.28 \\
\hline & Median & 3.00 & 3.00 & 3.00 & 3.00 & 3.00 \\
\hline & Min & 0.00 & 0.00 & 0.00 & 0.00 & 0.00 \\
\hline & Max & 12.00 & 12.00 & 12.00 & 12.00 & 12.00 \\
\hline & Pearson $\chi^{2}$ (male vs. female) & 0.12 & & & & \\
\hline & Pearson $\chi^{2}$ (dalit vs. mid/up) & 1.94 & & & & \\
\hline \multirow{3}{*}{$\begin{array}{l}\text { expansion of the business } \\
\text { ( } 1 \text { if other employees employed) }\end{array}$} & Mean & $38.28 \%$ & $16.67 \%$ & $42.75 \%$ & $36.20 \%$ & $39.31 \%$ \\
\hline & ttest (male vs. female) & $2.71^{* * *}$ & & & & \\
\hline & ttest (dalit vs. mid/up) & 0.39 & & & & \\
\hline
\end{tabular}

Source: survey RUME 2010 